\title{
A systematic multicellular spheroids screening approach lead to the identification of antineoplastic activity in three different plant extracts from the Egyptian flora
}

\author{
Walid Fayad $^{1}$, Salwa M. El-Hallouty ${ }^{1}$, May A. El-Manawaty ${ }^{1}$, Marwa M. Mounier ${ }^{1}$, Ahmed A. F. Soliman ${ }^{1}$, \\ Abeer A. Yousry ${ }^{2}$, Ayman A. Farghaly ${ }^{3}$, Maha A. Fahmy ${ }^{3}$, Zeinab M. Hasasn ${ }^{4}$, Stig Linder ${ }^{5,6}$, Khaled Mahmoud ${ }^{1 *}$ \\ ${ }^{1}$ Drug Bioassay-Cell Culture Laboratory, Pharmacognosy Department, Pharmaceutical and Drug Industries Division, National Research Centre, Dokki, \\ Giza, 12622, Egypt. ${ }^{2}$ Medicinal and Aromatic Plants Department, Pharmaceutical and Drug Industries Division, National Research Centre, Dokki, Giza, \\ 12622, Egypt. ${ }^{3}$ Genetics and Cytology Department, National Research Centre, Dokki, Giza, 12622, Egypt. ${ }^{4}$ Chemistry of Natural Compounds Department, \\ National Research Centre, Dokki, Giza, Egypt. ${ }^{5}$ Department of Medical and Health Sciences, Linköping University, Linköping, Sweden. ${ }^{6}$ Cancer Center \\ Karolinska, Department of Oncology and Pathology, Karolinska Institute, Stockholm, Sweden.
}

\section{ARTICLE INFO}

Article history:

Received on: 05/03/2017

Accepted on: 08/05/2017

Available online: 30/06/2017

Key words:

Anticancer, Plant extracts, Multicellular spheroids,

Screening, Pro-apoptotic,

Therapeutic window.

\begin{abstract}
Developing natural products as potential antineoplastic drugs is a meticulous process involving both compound isolation and biological testing. Many studies are based on primary screening using tumor cell viability as the readout followed by compound isolation. We here present an approach which utilizes both 2-D and 3-D cultured of tumor cells for screening and immortalized human non-transformed cells for counter screening. This procedure increases the precision of identifying tumor-specific cytotoxic compounds with interesting pharmacological properties. Using this straight-forward approach, we screened 500 plant extracts from the Egyptian flora for anticancer activity. The primary screen on 2-D cultured cells yielded 41 hits, 12 of which showed significant cytotoxicity on 3-D cultured cells. Of these, 4 extracts showed limited cytoxicity to normal cells. We conclude that only $\sim 10 \%$ of the cytotoxic extracts showed desired properties with regard to tumor parenchyme penetration and tumor-specific activity. Extracts from Euphorbia dendroides L. herb, Ononis vaginalis Vahl. herb and Quercus robur L. branches were found to induce tumor apoptosis and were considered the most promising. These three extracts showed significant inhibition in the Ehrlich ascites carcinoma in vivo model and did not show severe toxicity on healthy animals.
\end{abstract}

\section{INTRODUCTION}

Cell based screening will continue to serve as a major approach for anticancer drug discovery (Balis, 2002). The major advantage of such approach is the detection of drug efficacy within the context of the whole cell. The majority of cell based screening is performed on human tumor cell lines (HTCL) grown as monolayers. The large-scale screening being performed by the National Cancer Institute (NCI) is a prominent example (Shoemaker, 2006). However, there is an evident discrepancy between activity detected in vitro and that observed in vivo

\footnotetext{
* Corresponding Author

Email: khaledmmh2003 @ yahoo.com
}

(Hutchinson and Kirk, 2011). An explanation for such observation could be the lack of many characteristics of the in vivo tumors in the monolayers model. Solid tumors are three dimensional mass containing a hypoxic and quiescent, known to be resistant, subpopulation (Brown, 2007). Multicellular spheroids (MCS) have been introduced in the early 1970 s as a model to mimic solid tumors (Inch et al., 1970). This model represents many, but not all, of solid tumors features, and is considered of intermediate complexity between monolayers and in vivo tumors. MCS are three dimensional and include the hypoxic, quiescent cells observed in solid tumors (Roberts et al., 2009). In addition, several studies showed that the gene expression of MCS is more similar to that of in vivo tumors, and not to cells grown as monolayers (Takagi et al., 2007). Thus, cancer MCS are considered as an optimization in the cell based screening procedures. 
Indeed, many standard anticancer drugs used in the clinic showed poor activity on cancer MCS (Mellor et al., 2005). Doxorubicin, taxol and vinblastine are examples. Furthermore, studies showed that there is a high correlation between activity of drugs on cancer MCS and tumors in vivo (Kobayashi et al., 1993). Consequently, MCS are of more predictive value for drug efficacy compared to conventional monolayers model.

In the present study, an integrative approach is presented for the selection and prioritization among a set of plant extracts showing anticancer activity. 500 plants extracts from the Egyptian flora were randomly selected to be screened for their anticancer activity against HCT116 human colon carcinoma cell line. The procedures started with a primary screen of the plant extracts library for cytotoxicity on HCT116 monolayers. 41 extracts showed promising activity with $>70 \%$ cytotoxicity. To define which of which is the most promising, the active hits were secondarily screened on the same cell line but grown as MCS. This secondary screen is capable of defining extracts which are able of penetrating the tumor mass. High penetrability is an essential characteristic of efficient drug in treatment of solid tumors. Conventional monolayers are blind to differentiate between penetrating and non-penetrating drugs. In order to early select for extracts with wide therapeutic index, the 12 MCS active extracts were counter screened on the normal human epithelial retinal RPE1 cell line, grown as spheroids. This cell line is totally quiescent when grown as MCS, mimicking the majority of adult human normal tissue. 4 extracts out of the 12 HCT116 spheroids hits, did not show significant or any cytotoxicity on the normal spheroids cells. Apoptosis is considered as an interesting end point, and has been shown that many drugs in the clinic act through the induction of apoptosis in cancer cells. Three out of the four extracts were significantly pro-apoptotic. Thus, the present MCS based approach along with pro-apoptosis measurement was able to direct the research focus into only 3 extracts out of 41 active anticancer extracts.

The selected 3 extracts were then subjected to toxicological studies in animals: i) short term toxicity, ii) liver and kidney toxicity and iii) mutagenic effect on somatic and germ cells (using chromosomal aberration test). In addition, the 3 extracts were evaluated for their antitumor activity in vivo, in Ehrlich ascites carcinoma model. Interestingly, the selected hits showed significant in vivo anticancer activity and were in general safe on animals, indicating a correlation with the previously obtained in vitro results.

Collectively, the present study is introducing an approach for prioritizing among a set of active cancer monolayers hits. This approach was able to prioritize 3 extracts out of 41 active extracts. After the monolayers screen, the hits were secondarily screened on cancer MCS, and the active MCS hits were counter screened for identification of safe extracts on normal cells. Screening for proapoptotic activity is utilized to obtain an insight for further mechanistic studies. Following the in vitro studies, in vivo toxicological and antitumor studies were performed. Confirming the obtained in vitro results, the selected extracts showed potent in vivo activity on Ehrlich ascites carcinoma animal model, without inducing remarkable toxicity on healthy mice.

\section{MATERIAL AND METHODS}

\section{Plant material}

Amount of the attainable wild and cultivated plants, were collected randomly from different habitat in Egypt. Voucher specimens were prepared and deposited in the Herbarium of the Pharmacognosy Department, National Research Centre, Egypt and taxonomical nomenclature was performed according to Boulos (1999, 2000, 2002, 2005) (Boulos) and Huxley et al. (1992) (Huxley et al., 1992).

\section{Preparation of extracts}

The collected plants were separated into parts. 500 different parts were obtained (cf. Table 1). Plant samples were dried in solar ovens at $45^{\circ} \mathrm{C}$ and then grinded. Sufficient weight of each plant powder was exhaustively extracted with $95 \%$ methanol. The methanol extracts were filtered, evaporated under vacuum at $35^{\circ} \mathrm{C}$, freeze dried and stored at $-20{ }^{\circ} \mathrm{C}$. The freeze dried plant extracts were deposited at the Extract Bank of the In-Vitro Bioassay Laboratory, National Research Center, Egypt.

\section{Cell culture}

HCT116 human colon carcinoma cell line was obtained from ATCC and was maintained in McCoy's 5A modified medium/10\% FBS while hTERT-RPE1 cell line was obtained from CLONTECH. hTERT-RPE1 is an immortalized human retinal epithelial cell line that stably expresses human telomerase reverse transcriptase (hTERT).hTERT-RPE1 was maintained in DMEM:F12 Medium/10\% FCS. Both cell lines were incubated at $37^{\circ} \mathrm{C}$ in $5 \% \mathrm{CO} 2$ and $95 \%$ humidity. Cells were sub-cultured using trypsin versene $0.15 \%$.

\section{A- Cytotoxicity bioassay on HCT116 monolayers}

After $24 \mathrm{~h}$ of seeding 10000 cells per well (in 96-well plates), a $100 \mathrm{ppm}$ final concentration of the test extracts were added in triplicates. The cells were treated for $24 \mathrm{~h} .1 \mu \mathrm{M}$ staurosporine was used as positive control and 0.5\% DMSO was used as a negative control. Cytotoxicity was determined using MTT [3-(4,5-dimethylthiazol-2-yl)-2,5-diphenyltetrazolium bromide] assay as described by Mosmann in 1983 (Mosmann, 1983). Cytotoxicity was calculated according to the following equation: $[1-(\operatorname{av}(x)) /(\operatorname{av}(\mathrm{NC}))] * 100$. (Mostafa et al 2014)

Where: Av: average, X: absorbance of sample, NC: absorbance of negative control.

Absorbance was measured at $595 \mathrm{~nm}$ with reference $690 \mathrm{~nm}$.

\section{B. Cytotoxicity bioassay on HCT116 and hTERT-RPE1 multicellular spheroids}

Spheroids were generated as previously described (Fayad et al., 2011; Awad et al., 2016). FBS was filtered through $0.45 \mu \mathrm{m}$ 
filter, to remove any particulates that cause deformation in the spheroids. 10000 cells of HCT116 and 50000 cells of hTERTRPE1 were added to each well of poly-HEMA-coated round bottom 96-well plates. The wells were overfilled by adding $170 \mu \mathrm{L}$ media to obtain convex curvature. Plasticine spacers were placed in the four corners of plates to prevent the lids from touching the surface of the media. The plates were inverted and incubated for $24 \mathrm{~h}$ on a rotary shaker. Plates were flipped back to normal position to allow the formed aggregates to settle down in the bottom of the wells. Excess medium was removed using a syringe needle connected to a pump and plates were incubated for more 4 days. By this time, mature spheroids were generated $(\sim 500 \mu \mathrm{m}$ in diameter). Before treatment, media was changed and were adjusted to $200 \mu \mathrm{l}$. Test extracts were added in triplicates to a final concentration of $100 \mathrm{ppm}$ and were incubated for $120 \mathrm{~h} .1 \mu \mathrm{M}$ final concentration staurosporine was used as positive control and $1 \mu \mathrm{l}$ DMSO was used as a negative control. At the end of incubation, cytotoxicity was determined using the acid phosphatase method (Friedrich et al., 2007). After washing twice with $250 \mu \mathrm{l}$ PBS buffer, $100 \mu \mathrm{l}$ of $0.1 \mathrm{M}$ sodium acetate, $0,1 \%$ Triton $\mathrm{X}-100$, pnitrophenylphosphate (Pierce Biotechnology Inc, Rockford, IL) were added to each well and incubated for 1.5 hour at $37^{\circ} \mathrm{C}$. after incubation, $10 \mu 11 \mathrm{~N} \mathrm{NaOH}$ stop solution was added to each well and absorbance was read at $405 \mathrm{~nm}$. Cytotoxicity was calculated according to the following equation:

\section{$[1-(\operatorname{av}(\mathrm{x})) /(\operatorname{av}(\mathrm{NC}))]^{*} 100$.}

Where: Av: average, X: absorbance of sample, NC: absorbance of negative control.

\section{Pro-apoptotic activity determination on HCT116 monolayers}

10000 cells per well were seeded in 96-well plates and left for $24 \mathrm{~h}$. $100 \mathrm{ppm}$ final concentration of the test extracts were added in triplicates and the cells were treated for $24 \mathrm{~h} .40 \mu \mathrm{M}$ cisplatin was used as positive control, while $0.5 \%$ DMSO was used as negative control. Pro-apoptotic activity was determined using the M30 CytoDeath ELISA assay (VLV Bio AB, Stockholm, Sweden). Apoptosis was analyzed after addition of NP40 to the culture medium (to $0.1 \%$ ) to extract caspase-cleaved CK18 and to include material released to the medium from dead cells. Caspase-cleaved cytokeratin-18 (K18-Asp396) was determined in $25 \mu 1$ medium/extract according to manufacturer instructions.

Results are expressed as fold increase of the negative control (FINC) background caused by spontaneous apoptosis according to the following formula:

$\mathrm{FINC}=\mathrm{A} 450$ (test extract)/A450 (negative control). Where A450 nm is the absorbance obtained at $450 \mathrm{~nm}$.

\section{In vivo toxicological studies}

Swiss albino mice were selected for these studies. Animals were housed in groups in stainless steel cages and kept under standard laboratory conditions. They were given pelleted food and drinking water ad libitum. The mice were acclimatized to the laboratory conditions for at least five days prior to commencement of the experiments.

\section{A. Short term toxicity and determination of median lethal dose $\left(L D_{50}\right)$}

Acute oral toxicity test was performed as per OECD guidelines. All healthy animals weighing 20-25 gm were randomly distributed into one control group and three treated groups, containing 6 animals per group . $\mathrm{LD}_{50}$ of the promising extracts was determined using the method described by Wilbrandt (Wilbrandt, 1952). Groups 1, 2 and 3 were orally administered $250,500,1000$ and $2000 \mathrm{mg} / \mathrm{kg}$ body weight of each methanol extract, respectively. The control group received vehicle alone (DMSO). The $\mathrm{LD}_{50}$ of each extract was calculated according to the formula:

$\mathrm{LD}_{50}=\mathrm{Dm}-\Sigma(\mathrm{Zxd}) / \mathrm{n}$

Where, Dm is the minimum dose which kills all animals in the group, $\mathrm{Z}$ is the mean of dead animals in two successive groups, $\mathrm{d}$ is the constant factor between two successive groups, $\mathrm{n}$ is the number of animals of each group; and $\Sigma$ is the sum of (Zxd).

The animals were observed continuously for first 24 hours and after 14 days for any signs of behavioral changes, mortality and body weight.

\section{B. Effect of promising plant extracts on liver and kidney function}

Animal handling and experimental procedures were approved by the Institutional Animal Ethics Committee, NRC (Reg No: 16014) and experiments were performed in accordance with the "Guide for the care and use of laboratory animals" (NIH, 1985) and "Committee for the purpose of control and supervision on experimental animals. Study animals were randomized into four groups of six animals each. The mode of administration to all the groups was given through gastric intubation day after day for 2weeks and groups as following:

1- Group (1) control mice received $200 \mu 1$ distilled water.

2- Group (2) mice received $1 / 10$ of $\mathrm{LD}_{50}$ dose of Euphorbia dendroides extract.

3- Group (3) mice received $1 / 10$ of $\mathrm{LD}_{50}$ dose of Ononis vaginalis extract.

4- Group (4) mice received , 1/10 of LD50 dose of Quercus robur extract.

5- group (5) mice received 200ul DMSO.

At the end of the experimental period (15 days), all the mice were kept 12 hours fasting and anesthetized using ketamine chloride ( $24 \mathrm{mg} / \mathrm{kg}$ body weight) by intramuscular injection and sacrificed by cervical decapitation. Blood was collected in clean dry test tubes, serum obtained was used for various biochemical estimations. The activity of both serum aspartate aminotransferase (AST) and alanine aminotransferase (ALT) were assayed by using the diagnostic kit based on the method of Reitman and Frankel (Reitman and Frankel, 1957). Serum creatinine was determined by the color reaction method described by Jaffe (Husdan and Rapoport, 1968). Serum bilirubin was assayed based on the 
modified method of Malloy and Evelyn (Malloy and Evelyn, 1937)

\section{In vivo antitumor activity on Ehrlich ascites carcinoma model}

Ehrlich ascites carcinoma model (Geran, 1972) was utilized to evaluate the antitumor activity of the selected promising plant extracts. Ehrlich Ascites Carcinoma (EAC) was obtained from National Cancer Institute, Cairo, Egypt, and they were used at a concentration of $2 \times 10^{6}$ cell/mouse.

\section{Experimental design}

Female albino mice were obtained from animal house; National Research Centre and ranging in weight 20-25g. They were fed on standard diet and water ad libitum. 24h after tumor inoculation, mice were randomly subdivided into six groups (10 mice /group). Plant extracts were dissolved in DMSO and were injected orally at $48 \mathrm{~h}$ intervals at dose of 1/10 LD50.

Group 1: Received saline orally for ten consecutive days and served as negative control.

Group 2: Received vehicle DMSO and was injected with EAC (2x106cell /mice) for ten consecutive days and served as (DMSO group).

Group 3: Infected mice treated with $5-\mathrm{FU}$ at dose $20 \mathrm{mg} / \mathrm{kg}$ b.wt./day for ten consecutive days (intraperitoneal injection).

Group 4: Infected mice injected with EAC and incubated for $24 \mathrm{hr}$ then they were administered Euphorbia dendroides extract orally at dose 1/10 LD50 for ten consecutive days and served as treated group.

Group 5: Infected mice injected with EAC and incubated for 24hr then they were administered Ononis vaginalis extract orally at dose 1/10 LD50 for ten consecutive days and served as treated group.

Group 6: Infected mice injected with EAC and incubated for 24hr then they were administered extract Quercus robur branches extract. orally at dose 1/10 LD50 for ten consecutive days and served as treated group.

Mice were fasting for $18 \mathrm{hrs}$ for estimation hematological parameters then blood samples were collected from cardiac puncture, six mice/ group only, after 10 days of extract and 5-FU administration. four mice were kept alive to check the increase in life span of the tumor bearing hosts [9]. The efficacy of extracts were evaluated by: packed cell volume, Median survival time (MST) and increase in life span percentage.

Efficacy was evaluated by:

1. Viable and non-viable cell count.

2. Tumor volume measurement.

3. Median survival time (MST)

4. Tumor weight measurement.

5. Percentage increase in life span.

The median survival time of animals due to tumor burden was noted till all the animals were dead, and the percentage increase in life span was calculated using the formula:

\section{$(\mathrm{T}-\mathrm{C}) / \mathrm{C}) \times 100$}

Where $\mathrm{T}$ and $\mathrm{C}$ represent the number of days that treated and control animals survived, respectively (Sunila and Kuttan, 2004).

Data are presented as mean \pm SE. Statistical independent t-test and one way anova were carried out for data analysis followed by post Hoc test $(n=3, p<0.05)$. Data are followed with increment $\%$ or decrease $\%$ as compared to tumor bearing mice while increase in life span was compared to FU group.

\section{Chromosomal aberrations in somatic cells and chromosomal abnormalities in germ cells}

$1 / 10 \mathrm{mg}$ of $\mathrm{LD}_{50}$ was I.P. administered to healthy mice for 15 days day after day. Chromosome preparations from bone marrow (somatic cells) carried out according to the method of Yosida and Amano (Yosida and Amano, 1965). 100 well spread metaphases were analyzed per mouse. Metaphases with gaps, chromatid break and fragments, under $100 \mathrm{X}$ magnification with a light microscope (Olympus, Saitama, Japan)were recorded. Concerning Chromosome abnormalities in germ cells, chromosome preparations from spermatocytes (germ cells) were made according to the technique of Evans et al (Evans et al., 1964). 100 well spread diakinase-metaphase (I) cells were analyzed per animal for chromosomal aberrations. Metaphases with X-Y univalents and autosomal univalents were recorded.

Data are presented as mean \pm SE. Statistical independent t-test and one way anova were carried out for data analysis followed by post Hoc test $(n=3, p<0.05)$. Data are followed with increment $\%$ or decrease $\%$ as compared to tumor bearing mice while increase in life span was compared to FU group.

\section{RESULTS}

\section{Cytotoxicity and pro-apoptosis assessment assays}

On screening 500 plant extracts on HCT116 monolayers, 41 extracts showed $>70 \%$ cyototoxicity at $100 \mu \mathrm{g} / \mathrm{ml}$. The active plant extracts details are listed in table 1 . The extracts are arranged according to their cytotoxic effect in descending order.

The cytotoxicity results of the 41 extracts at $100 \mu \mathrm{g} / \mathrm{ml}$ on HCT116 monolayers and spheroids and on RPE1 normal cells spheroids and their pro-apoptotic activity are represented in table 2.

In this study, the criteria for selecting promising extracts for further studies were: $>70 \%$ cytototixicity on HCT116 monolayers, $\geq 60 \%$ cytotoxicity on HCT116 spheroids, <10\% cyototoxicity on RPE1 spheroids, and inducing $>3.5$ fold increase in apoptotis induction compared to the negative control (FINC). These criteria were found to be applied to three extracts and were chosen for further evaluation for in-vivo anticancer activity and toxicity in experimental animals described in the following sections. These three extracts are namely:

1 Euphorbia dendroides L. herb extract (extract no. 23).

2 Ononis vaginalis Vahl. herb extract (extract no. 34).

3 Quercus robur L. branch extract (extract no. 38).

The results of these extracts are expressed in figure 1. 
Table 1: Details of plants that showed $>70 \%$ cytotoxicity on HCT116 monolayers at $100 \mu \mathrm{g} / \mathrm{ml}$.

\begin{tabular}{|c|c|c|c|}
\hline $\begin{array}{l}\text { Extract } \\
\text { number }\end{array}$ & Plant name & Part & Family \\
\hline 1 & Furcraea foetida ( L.) Haw. ( F. gigantea Venten ) & $\mathrm{L}$ & Agavaceae \\
\hline 2 & Schefflera arboricola (Hayata) Merr. & $L \& B r$ & Araliaceae \\
\hline 3 & Convolvulus arvensis $\mathrm{L}$. & Weed & Convolvulaceae \\
\hline 4 & Centaurea sp. & $\mathrm{H}$ & Compositae \\
\hline 5 & Polyalthia longifolia Benth. \& Hook. f. & Bark & Annonaceae \\
\hline 6 & Silene succulenta Forssk. & $\mathrm{H}$ & Caryophyllaceae \\
\hline 7 & Hyoscyamus desertorum (Asch. ex Boiss.) Tackholm. & $\mathrm{H}$ & Solanaceae \\
\hline 8 & Agave americana L. cv. var Marginata & $\mathrm{L}$ & Agavaceae \\
\hline 9 & Gingko biloba $\mathrm{L}$ & $\mathrm{L}$ & Gingkoaceae \\
\hline 10 & Agave franzosinii bak. & Aerial parts & Agavaceae \\
\hline 11 & Ficus mysoranus Roth. & $\mathrm{L} \& \mathrm{Br}$ & Moraceae \\
\hline 12 & Agava angustifolia Haw. Cv. Marginata & $\mathrm{L}$ & Agavaceae \\
\hline 13 & Verbascum sinaiticum Benth. & $\mathrm{H}$ & Scrophulariaceae \\
\hline 14 & Amorpha fruticosa $\mathrm{L}$. & $\mathrm{L} \& \mathrm{Br}$ & Leguminosae \\
\hline 15 & Petunia hybrida Hort. & $\mathrm{L} \& \mathrm{Br}$ & Solanaceae \\
\hline 16 & Dovyalis caffra (Hook.F.\&Harv)Warb. (Aberia caffra Hook.F.\& Harv) & $\mathrm{L} \& \mathrm{Br}$ & Flacourtiaceae \\
\hline 17 & Furcraea selloa $C$.Koch. var. marginata Trel. & $\mathrm{L}$ & Agavaceae \\
\hline 18 & Lantana camara $\mathrm{L}$. & $\mathrm{L}$ & Verbenaceae \\
\hline 19 & Agave lophantha Poselgeri & $\mathrm{L}$ & Agavaceae \\
\hline 20 & Euphorbia pseudocactus A. Berger & Aerial parts & Euphorbiaceae \\
\hline 21 & Enterolobium timbouva Mart. & $\mathrm{L} \& \mathrm{Fl} \& \mathrm{Fr}$ & Leguminosae \\
\hline 22 & Putranjiva roxburghii Wall. & Bark & Euphorbiaceae \\
\hline 23 & Euphorbia dendroides L. & $\mathrm{H}$ & Euphorbiaceae \\
\hline 24 & Pinus halepensis Miller & $\mathrm{L}$ & Pinaceae \\
\hline 25 & Morus rubra L. & $\mathrm{Br}$ & Moraceae \\
\hline 26 & Gingko biloba L. & Bark & Ginkgoaceae \\
\hline 27 & Enterolobium timbouva Mart. & $\mathrm{Br}$ & Leguminosae \\
\hline 28 & Synadinium grantii Hook. f. & $\mathrm{H}$ & Euphorbiaceae \\
\hline 29 & Citrullus colocynthis (L.) Schrad. & $\mathrm{Fr}$ & Cucurbitaceae \\
\hline 30 & Centaurea pallescens Delile & $\mathrm{H}$ & Compositae \\
\hline 31 & Pluchea dioscoridis (L.) DC. & $\mathrm{H}$ & Compositae \\
\hline 32 & Convolvulus lanatus Vahl. & $\mathrm{H}$ & Convolvulaceae \\
\hline 33 & Onopordum alexandrinum Boiss. & $\mathrm{H}$ & Compositae \\
\hline 34 & Ononis vaginalis Vahl. & $\mathrm{H}$ & Leguminosae \\
\hline 35 & Poa annua $\mathrm{L}$. & Weed & Graminae \\
\hline 36 & Euphorbia retusa Forsk. & $\mathrm{H}$ & Euphorbiaceae \\
\hline 37 & Mathiola incana L.RBr & $\mathrm{L} \& \mathrm{Br}$ & Cruciferae \\
\hline 38 & Quercus robur L. & $\mathrm{Br}$ & Fagaceae \\
\hline 39 & Verbascum letournexii Asch. & $\mathrm{H}$ & Scrophulariaceae \\
\hline 40 & Cynanchum acutum L. & Fr. & Asclepiadaceae \\
\hline 41 & Pulicaria crispa (Forssk.) & $\mathrm{H}$ & Compositae \\
\hline
\end{tabular}

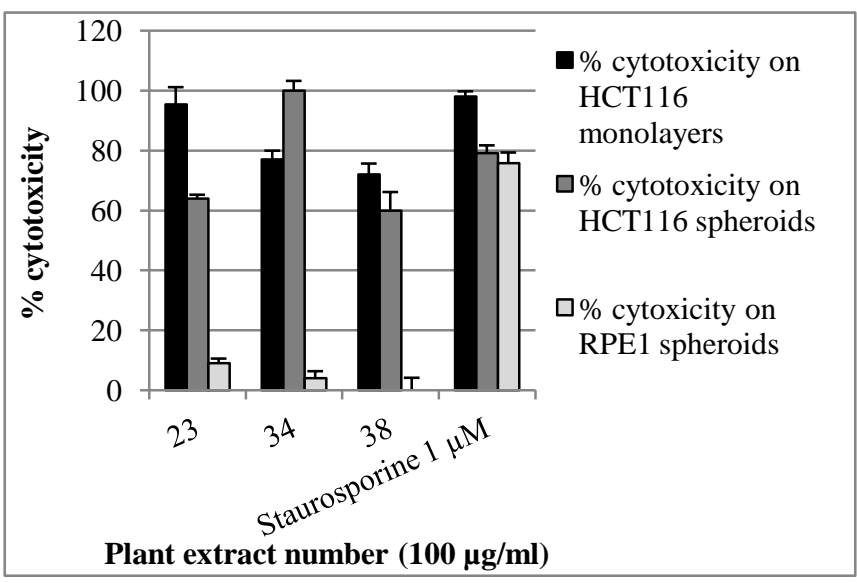

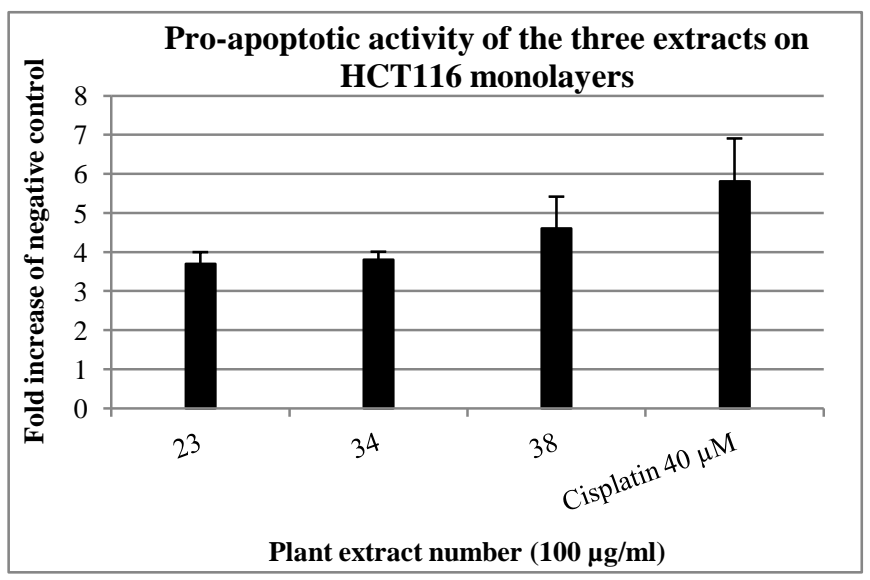

B

Fig. 1: A. Cytototoxicity of the three selected plant extracts at $100 \mu \mathrm{g} / \mathrm{ml}$ on HCT116 monolayers and spheroids and on RPE1 spheroids. B. Pro-apoptotic activity of the three selected plant extracts on HCT116 monolayers. 
Table 2: Cytotoxicity and pro-apoptotic activity of the selected 41 extracts tested at $100 \mu \mathrm{g} / \mathrm{ml}$.

\begin{tabular}{|c|c|c|c|c|}
\hline Extract number & \% cytotoxicity HCT116 monolayers & \% cytotoxicity HCT116 spheroids & \% cytoxicity RPE1 spheroids & FNCI $^{*}$ \\
\hline 1 & 100 & 0 & 77 & 0.9 \\
\hline 2 & 100 & 64 & 49 & 0.8 \\
\hline 3 & 100 & 67 & 59 & 0.8 \\
\hline 4 & 100 & 0 & 44 & 0.6 \\
\hline 5 & 100 & 88 & 76 & 1.2 \\
\hline 6 & 100 & 0 & 70 & 0.7 \\
\hline 7 & 100 & 51 & 100 & 0.9 \\
\hline 8 & 100 & 100 & 0 & 0.6 \\
\hline 9 & 100 & 57 & 15 & 0.7 \\
\hline 10 & 100 & 34 & 43 & 0.8 \\
\hline 11 & 100 & 48 & 3 & 2.0 \\
\hline 12 & 100 & 32 & 0 & 0.7 \\
\hline 13 & 100 & 32 & 31 & 0.6 \\
\hline 14 & 99.5 & 14 & 100 & 1.1 \\
\hline 15 & 99.4 & 63 & 60 & 2.1 \\
\hline 16 & 98.9 & 0 & 72 & 1.2 \\
\hline 17 & 98.6 & 15 & 71 & 0.9 \\
\hline 18 & 98.6 & 3 & 42 & 1.5 \\
\hline 19 & 98 & 91 & 69 & 0.9 \\
\hline 20 & 97.7 & 71 & 35 & 0.8 \\
\hline 21 & 96.4 & 0 & 82 & 0.9 \\
\hline 22 & 96 & 97 & 48 & 3.6 \\
\hline 23 & 95.4 & 64 & 9 & 3.7 \\
\hline 24 & 95 & 33 & 0 & 0.6 \\
\hline 25 & 95 & 51 & 0 & 0.8 \\
\hline 26 & 94 & 50 & 21 & 0.9 \\
\hline 27 & 93.4 & 0 & 85 & 0.8 \\
\hline 28 & 88.3 & 68 & 31 & 4.9 \\
\hline 29 & 80 & 1 & 26 & 3.8 \\
\hline 30 & 79.9 & 17 & 39 & 0.9 \\
\hline 31 & 78.5 & 2 & 42 & 1.3 \\
\hline 32 & 78.5 & 14 & 61 & 0.8 \\
\hline 33 & 77.8 & 36 & 65 & 0.8 \\
\hline 34 & 77.1 & 100 & 4 & 3.8 \\
\hline 35 & 75 & 42 & 5 & 1.4 \\
\hline 36 & 74.2 & 34 & 0 & 1.0 \\
\hline 37 & 72.4 & 27 & 34 & 1.7 \\
\hline 38 & 72.1 & 60 & 0 & 4.6 \\
\hline 39 & 71.5 & 20 & 29 & 0.6 \\
\hline 40 & 71 & 0 & 0 & 1.1 \\
\hline 41 & 70.7 & 0 & 10 & 1.8 \\
\hline
\end{tabular}

"FINC: fold increase of negative control (of spontaneous background apoptosis occurring in negative control cells).

Table 3: lethal dose $\mathrm{LD}_{50}$ of Euphorbia dendroides methanolic extract.

\begin{tabular}{cccccc}
\hline Dose (mg / kg b.wt.) & Number of mice & Number of dead mice & $\mathbf{Z}$ & $\mathbf{d}$ & $(\mathbf{Z}) \mathbf{x}(\mathbf{d})$ \\
\hline 100 & 6 & 0 & 0 & 100 & 150 \\
250 & 6 & 2 & 3 & 250 & 150 \\
500 & 6 & 4 & 4.5 & 500 & 750 \\
1000 & 6 & 5 & 5.5 & 1000 & 2250 \\
2000 & 6 & 6 & 5500 & \\
\hline
\end{tabular}

$\mathrm{LD}_{50}$ of Euphorbia dendroides methanolic extract $=558 \mathrm{mg} / \mathrm{kg}$.

\section{In vivo toxicological studies}

\section{A. Short term toxicity and determination of median lethal dose $\left(L D_{50}\right)$}

The behavioral patterns of animals were observed at first $24 \mathrm{~h}$ and followed by 14 days after the administration of the three promising extracts at different doses: 100, 250, 500 and 1000 $\mathrm{mg} / \mathrm{kg}$ body weight. Treated animals did not display significant changes in behavior, skin effects, breathing, impairment in food intake, water consumption and hair loss.
While half number of animals were dead at dose of 2000 $\mathrm{mg} / \mathrm{kg}$ body weight. Concerning Euphorbia dendroides extract (no. 23), negative changes in the behavioral patterns of animals were observed like decrease in food intake, weight loss and decrease in the activity at doses 100,250 and $500 \mathrm{mg} / \mathrm{kg}$ body weight and all animals died at $2000 \mathrm{mg} / \mathrm{kg}$.

The median lethal dose $\mathrm{LD}_{50}$ for promising extracts were 558,1479 and $1646 \mathrm{mg} / \mathrm{kg}$ for extracts number 23, 34 and 38, respectively (Table: $3,4,5$ ). 
Table 4: Lethal dose LD50 of Ononis vaginalis methanolic extract (34).

\begin{tabular}{cccccc}
\hline $\begin{array}{c}\text { Dose (mg / kg } \\
\text { b.wt.) }\end{array}$ & $\begin{array}{c}\text { Number of } \\
\text { mice }\end{array}$ & $\begin{array}{c}\text { Number of } \\
\text { dead mice }\end{array}$ & $\mathbf{Z}$ & $\mathbf{d}$ & $\mathbf{( Z ) \mathbf { x } ( \mathbf { d } )}$ \\
\hline 100 & 6 & 0 & 0 & 100 & 0 \\
250 & 6 & 0 & 0 & 150 & 0 \\
500 & 6 & 1 & 0.5 & 250 & 125 \\
1000 & 6 & 2 & 1.5 & 500 & 750 \\
2000 & 6 & 4 & 3 & 1000 & 2250 \\
\hline
\end{tabular}

LD50 of Ononis vaginalis methanolic extract $=1479 \mathrm{mg} / \mathrm{kg}$.

Table 5: Lethal dose LD50 of Quercus robur methanolic extract.

\begin{tabular}{cccccc}
\hline $\begin{array}{c}\text { Dose (mg / kg } \\
\text { b.wt.) }\end{array}$ & $\begin{array}{c}\text { Number of } \\
\text { mice }\end{array}$ & $\begin{array}{c}\text { Number of } \\
\text { dead mice }\end{array}$ & $\mathbf{Z}$ & $\mathbf{d}$ & $(\mathbf{Z}) \mathbf{x}(\mathbf{d})$ \\
\hline 100 & 6 & 0 & 0 & 100 & 0 \\
250 & 6 & 0 & 0 & 150 & 0 \\
500 & 6 & 1 & 0.5 & 250 & 125 \\
1000 & 6 & 1 & 1 & 500 & 500 \\
2000 & 6 & 3 & 2 & 1000 & 1500 \\
\hline
\end{tabular}

$\mathrm{LD}_{50}$ of Quercus robur methanolic extract $=1646 \mathrm{mg} / \mathrm{kg}$

\section{B. Effect of promising plant extracts on liver and kidney functions}

Table 6 shows the changes of biochemical parameters in the serum of mice treated by promising extracts.

Table 6: Changes of biochemical parameters in the serum of mice treated by promising extracts.

\begin{tabular}{ccccc}
$\begin{array}{c}\text { Extract } \\
\text { number/sample }\end{array}$ & $\begin{array}{c}\text { ALT (U/I) } \\
( \pm \text { SD })\end{array}$ & $\begin{array}{c}\text { AST(U/I) } \\
( \pm \text { SD })\end{array}$ & $\begin{array}{c}\text { Creat. } \\
(\mathbf{m g} / \mathbf{d l}) \\
( \pm \text { SD })\end{array}$ & $\begin{array}{c}\text { BUN. } \\
(\mathbf{m g} / \mathbf{d l}) \\
( \pm \text { SD })\end{array}$ \\
\hline 23 & $32( \pm 2.1)$ & $141( \pm 5.1)$ & $0.4( \pm 0.5)$ & $12( \pm 2.5)$ \\
34 & $84( \pm 1.5)$ & $374( \pm 8.1)$ & $0.4( \pm 0.2)$ & $37( \pm 1.9)$ \\
38 & $119( \pm 3.4)$ & $467( \pm 11.3 .1)$ & $0.4( \pm 0.1)$ & $49( \pm 3.1)$ \\
DMSO control & $43( \pm 1.9)$ & $179( \pm 5.4)$ & $0.4( \pm 0.2)$ & $23( \pm 0.9 .1)$ \\
Control & $48( \pm 1.1)$ & $159( \pm 3.5)$ & $0.5( \pm 0.4)$ & $21( \pm 1.6)$ \\
Normal values & $17-77$ & $54-298$ & $0.2-0.91$ & $8-33$ \\
\hline
\end{tabular}

There were no significant changes in the serum levels of creatinine in all treated groups. ALT, AST, bilirubin levels were in the normal range in the group treated by extract number 23 , while were elevated than normal levels in groups treated with extracts number 34 and 38. This indicated a relative safety of extract no. 23 at the given dose compared to extracts no. 34 and 38 in these experiments.
In vivo antitumor activity on Ehrlich ascites carcinoma model

\section{A. Viable and non-viable cell count}

For non treated group Ehrlich cell count reached $9.21 \times 10^{7}$ cell $/ \mathrm{ml}$ after twelve days of i.p. injection by $2 \times 10^{6}$ cell $/ \mathrm{ml}$. Treatment of tumor bearing mice with 5 -fluorouracil and extracts number 23, 34 and 38 significantly reduced no. of Ehrlich cells by $55.5,56.7,56.6$ and $58.3 \%$, respectively (table 7). It should be noted that all reduction percentage of total cell count and viable cell count were more than those of the 5-FU group with significant difference $p<0.001$.

\section{B. Effect of extracts no. 23, 34 and 38 on hematological parameters}

Induction of tumor by Ehrlich cells produced a great disturbance in all hematological parameters. It significantly reduced hemoglobin $\%$, hematocrit volume, red blood cells count, lymphocytes $\%$ and monocytes \% while total leukocytes count, basophils and Neutrophils \% were elevated (Table, 8). The used extracts were found to have potent effect in amelioration of Hemoglobin, hematocrit, RBC's and differential white blood cells. All extracts showed preferable effect on hematological parameters therefore bearing animals treated with tested extracts were recovered to normal level, negative control, in all recorded parameters and have a significant difference $p<0.05$.

\section{Effect of extracts number 23, 34 and 38 on survival parameters of tumor bearing mice}

Extracts number 23, 34 and 38 significantly reduced $(\mathrm{p}<0.05)$ tumor volume by $65.16,56.77$ and $67.42 \%$ respectively, (Table 9). Regarding tumor mass, it was significantly reduced by $81.99,77.01$ and $84.21 \%$ for extracts number 23,34 and 38 treated groups, respectively. Reduction in tumor volume and tumor weight significantly increase the median survival time of bearing mice by $214.29,192.23$ and $261.9 \%$ for extracts number 23, 34 and 38 treated groups, respectively, which increased life span. Extract number 38 showed the most potent effect on survival parameters which lead to an increase in the life span by $78.95 \%$ as compared to FU group.

Table 7: Effect of plant extracts on viable and non-viable tumor cell count.

\begin{tabular}{|c|c|c|c|c|c|}
\hline Parameter & $\begin{array}{c}\text { Tumor bearing group } \\
\text { (DMSO treated) }\end{array}$ & $\begin{array}{l}\text { 5-FU treated } \\
\text { group }\end{array}$ & $\begin{array}{c}\text { Extract } 23 \text { treated } \\
\text { group }\end{array}$ & $\begin{array}{c}\text { Extract } 34 \text { treated } \\
\text { group }\end{array}$ & $\begin{array}{c}\text { Extract } 38 \text { treated } \\
\text { group }\end{array}$ \\
\hline Total cell count & $9.21 \pm 1.03$ & $4.10 \times 10^{7}( \pm 0.98)$ & $3.98 \times 10^{7}( \pm 0.65)$ & $4.00 \times 10^{7}( \pm 0.45)$ & $3.84 \times 10^{7}( \pm 0.79)$ \\
\hline$\left(\mathrm{x} 10^{7}\right.$ cell $\left./ \mathrm{ml}\right)$ & & (55.4\% redution) & ( $56.7 \%$ reduction) & (56.5\% reduction) & (58.3\% reduction) \\
\hline Viable cell count $\left(\times 10^{7}\right.$ cell $\left./ \mathrm{ml}\right)$ & $8.85 \pm 1.10$ & $1.23( \pm 0.96)$ & $0.64( \pm 0.43)$ & $0.67( \pm 0.31)$ & $0.62( \pm 0.23)$ \\
\hline Non-viable cell count $\left(\times 10^{7}\right.$ cell $\left./ \mathrm{ml}\right)$ & $0.36 \pm 0.76$ & $2.87 \pm 0.72$ & $3.34 \pm 0.55$ & $2.67 \pm 0.85$ & $3.38 \pm 0.34$ \\
\hline Viable cell \% & $96.09 \pm 1.05$ & $20.06 \pm 0.68$ & $16.08 \pm 0.91$ & $17.45 \pm 0.46$ & $15.5 \pm 0.63$ \\
\hline Non-viable cell \% & $3.91 \pm 1.06$ & $79.94 \pm 0.52$ & $83.92 \pm 0.72$ & $82.55 \pm 0.99$ & $84.50 \pm 0.71$ \\
\hline
\end{tabular}

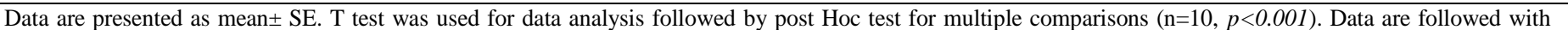
increment $\%$ or reduction $\%$. 
Table 8: Effect of 23, 34 and 38 on hematological parameters in Ehrlich Ascites carcinoma bearing mice.

\begin{tabular}{|c|c|c|c|c|c|c|c|}
\hline \multicolumn{2}{|c|}{$\begin{array}{lc}\text { Parameters } & \text { Groups } \\
\end{array}$} & Control group & Tumor bearing group & $\begin{array}{c}\text { FU-treated } \\
\text { group }\end{array}$ & $\begin{array}{l}23 \text { treated } \\
\text { group }\end{array}$ & $\begin{array}{l}34 \text { treated } \\
\text { group }\end{array}$ & $\begin{array}{l}38 \text { treated } \\
\text { group }\end{array}$ \\
\hline \multicolumn{2}{|c|}{ Hemoglobin (Hb) (g/dL) } & $12.88 \pm 0.73$ & $5.4 \pm 0.98(41.93 \%)$ & $12.39 \pm 0.85$ & $12.81 \pm 0.66$ & $12.41 \pm 0.93$ & $12.90 \pm 0.65$ \\
\hline \multicolumn{2}{|c|}{ Haematocrit (mm) } & $42.89 \pm 0.52$ & $17.98 \pm 0.99(41.92 \%)$ & $40.96 \pm 0.79$ & $42.66 \pm 0.55$ & $41.33 \pm 0.42$ & $42.96 \pm 0.29$ \\
\hline \multicolumn{2}{|c|}{ Red blood cells count $\quad(\mathrm{X} 106 / \mathrm{mm} 3)$} & $4.81 \pm 0.94$ & $1.89 \pm 1.01(39.29)$ & $4.13 \pm 0.96$ & $4.27 \pm 0.73$ & $4.13 \pm 0.81$ & $4.29 \pm 0.95$ \\
\hline \multicolumn{2}{|c|}{ Total leukocyte count $\quad\left(X_{10}^{3} / \mathrm{mm}^{3}\right)$} & $12.05 \pm 0.59$ & $31.71 \pm 2.61(263 \%)$ & $17.68 \pm 1.04$ & $14.33 \pm 0.82$ & $16.72 \pm 1.02$ & $12.11 \pm 0.96$ \\
\hline \multirow{5}{*}{ 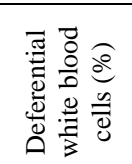 } & Basophile \% & $3.68 \pm 0.72$ & $5.22 \pm 0.84(141.85 \%)$ & $4.00 \pm 0.61$ & $3.80 \pm 0.95$ & $3.92 \pm 0.73$ & $3.72 \pm 0.82$ \\
\hline & Eosinophile \% & $2.30 \pm 0.61$ & $2.21 \pm 0.15$ & $2.00 \pm 0.44$ & $2.17 \pm 0.82$ & $2.28 \pm 0.41$ & $2.29 \pm 0.64$ \\
\hline & Neutrophile \% & $28.75 \pm 0.36$ & $65.00 \pm 0.68(226.09 \%)$ & $30.23 \pm 0.17$ & $30.14 \pm 0.19$ & $28.00 \pm 0.75$ & $28.62 \pm 0.32$ \\
\hline & Lymphocyte \% & $60.25 \pm 0.71$ & $25.32 \pm 0.11(42.02 \%)$ & $55.18 \pm 0.37$ & $57.33 \pm 0.16$ & $61.32 \pm 0.53$ & $60.00 \pm 0.81$ \\
\hline & Monocytes \% & $5.02 \pm 0.53$ & $2.25 \pm 0.26(44.83 \%)$ & $8.59 \pm 0.28$ & $6.56 \pm 0.48$ & $4.48 \pm 0.27$ & $5.37 \pm 0.11$ \\
\hline
\end{tabular}

Data are presented as mean \pm SE. ANOVA one-way was used for data analysis followed by post Hoc test for multiple comparisons ( $\mathrm{n}=3, p<0.05$ ). Data are followed with increment $\%$ or decrease $\%$. Bearing mice were compared to ve-control group while treated groups were compared to bearing group.

Table 9. Effect of plant extracts on tumor growth and survival parameters.

\begin{tabular}{|c|c|c|c|c|c|}
\hline $\begin{array}{ll}\text { Parameter } & \text { Groups } \\
\end{array}$ & $\begin{array}{l}\text { Tumor bearing } \\
\text { mice group }\end{array}$ & Extract 23 treated group & $\begin{array}{c}\text { Extract } 34 \text { treated } \\
\text { group } \\
\end{array}$ & $\begin{array}{c}\text { Extract } 38 \text { treated } \\
\text { group }\end{array}$ & 5-FU treated group \\
\hline Tumor volume $\left(\mathrm{cm}^{3}\right)$ & $3.1 \pm 1.02$ & $\begin{array}{c}1.08 \pm 0.54 \\
(65.16 \% \text { reduction })\end{array}$ & $\begin{array}{c}1.34 \pm 0.77 \\
(56.77 \% \text { reduction })\end{array}$ & $\begin{array}{c}1.01 \pm 0.62 \\
(67.42 \% \text { reduction })\end{array}$ & $\begin{array}{c}1.21 \pm 0.99 \\
(60.96 \% \text { reduction })\end{array}$ \\
\hline Tumor mass (grams) & $3.61 \pm 0.86$ & $\begin{array}{c}0.65 \pm 0.34 \\
(81.99 \% \text { reduction })\end{array}$ & $\begin{array}{c}0.83 \pm 0.57 \\
(77.01 \% \text { reduction })\end{array}$ & $\begin{array}{c}0.57 \pm 0.72 \\
(84.21 \% \text { reduction })\end{array}$ & $\begin{array}{c}0.71 \pm 0.46 \\
(80.33 \% \text { reduction })\end{array}$ \\
\hline MST (Median survival time) & $21 \pm 0.98$ & $\begin{array}{c}45 \pm 0.36 \\
(214.29 \% \text { increment })\end{array}$ & $\begin{array}{c}41 \pm 0.25 \\
\text { (195.23\% increment) }\end{array}$ & $\begin{array}{c}55 \pm 0.41 \\
(261.90 \% \text { increment })\end{array}$ & $\begin{array}{c}40 \pm 1.03 \\
\text { (190.47\% increment) }\end{array}$ \\
\hline Increase in life span\% & --- & $\begin{array}{c}114.28 \pm 0.81 \\
(25.21 \% \text { increment })\end{array}$ & $\begin{array}{c}95.24 \pm 0.53 \\
(5.27 \% \text { increment })\end{array}$ & $\begin{array}{c}161.90 \pm 0.24 \\
(78.95 \% \text { increment })\end{array}$ & $90.47 \pm 0.72$ \\
\hline
\end{tabular}

Table 10: Types and percentage of metaphases with chromosomal aberrations induced in mouse bone marrow cells after treatment with different extracts dissolved in DMSO for 1 and 2 weeks in vivo.

\begin{tabular}{|c|c|c|c|c|c|c|c|c|c|}
\hline \multirow{2}{*}{ Treatment } & \multirow{2}{*}{$\begin{array}{c}\text { Treatment } \\
\text { period } \\
\text { (week) }\end{array}$} & \multicolumn{2}{|c|}{ Abnormal metaphases } & \multicolumn{6}{|c|}{ No. of metaphases with different types of chrom. aberrations } \\
\hline & & No. & $\%$ Mean $( \pm$ SE) & $\begin{array}{c}\text { Chromatid } \\
\text { Gap }\end{array}$ & $\begin{array}{c}\text { Chromatid } \\
\text { Break }\end{array}$ & $\begin{array}{c}\text { Fragment } \\
\text { and/or break }\end{array}$ & Delation & C.F. & M.A. \\
\hline Negative control (untreated) & - & 15 & $3.0( \pm 0.45)$ & 9 & 1 & 5 & 0 & 0 & 0 \\
\hline \multirow{2}{*}{ DMSO } & 1 & 28 & $5.6\left( \pm 0.60^{a}\right)$ & 9 & 7 & 12 & \multirow{2}{*}{0} & \multirow{2}{*}{0} & \multirow{2}{*}{0} \\
\hline & 2 & 48 & $9.60\left( \pm 0.48^{\mathrm{a}}\right)$ & 22 & 11 & 15 & & & \\
\hline \multirow{2}{*}{ Extract 23} & 1 & 18 & $3.6( \pm 0.48)$ & 10 & 3 & 5 & \multirow{2}{*}{0} & \multirow{2}{*}{0} & \multirow{2}{*}{0} \\
\hline & 2 & 20 & $4.0\left( \pm 0.52^{\circ}\right)$ & 11 & 3 & 6 & & & \\
\hline Extract 34 & 1 & 25 & $\begin{array}{c}5.0( \pm 0.7) \\
4.60\left(+42^{\mathrm{b}}\right)\end{array}$ & 7 & $\begin{array}{l}6 \\
7\end{array}$ & 12 & 0 & 0 & 0 \\
\hline \multirow{2}{*}{ Extract 38} & 1 & 11 & $2.2\left( \pm 0.68^{b}\right)$ & 9 & 1 & 1 & \multirow[b]{2}{*}{0} & \multirow[b]{2}{*}{0} & \multirow[b]{2}{*}{0} \\
\hline & 2 & 19 & $3.8\left( \pm 0.42^{\mathrm{b}}\right)$ & 14 & 3 & 2 & & & \\
\hline $\begin{array}{l}\text { Positive control: cyclophosphamide at } \\
\text { dose } 20 \mathrm{mg} / \mathrm{kg} \text { body weight for } 24 \mathrm{hrs}\end{array}$ & $24 \mathrm{~h}$ & 121 & $32.27\left( \pm 1.29^{\mathrm{a}}\right)$ & 23 & - & 57 & 7 & 4 & 30 \\
\hline
\end{tabular}

Total number of examined metaphases $=500$ metaphase (5 animals/ group); C.F.: Centric Fusions; M.A.: Multiple Aberrations.

a: Significant compared to negative control $(\mathrm{p}<0.01)$; b: Significant compared to $\operatorname{DMSO}(\mathrm{p}<0.01)$.

Table 11: Types and percentage of metaphases with chromosomal aberrations induced in mouse spermatocyte cells after treatment with different extracts dissolved in DMSO for 1 and 2 weeks in vivo.

\begin{tabular}{|c|c|c|c|c|c|c|c|}
\hline \multirow[t]{2}{*}{ Treatment } & \multirow{2}{*}{$\begin{array}{c}\text { Treatment } \\
\text { period (week) }\end{array}$} & \multicolumn{2}{|c|}{ Abnormal metaphases } & \multicolumn{4}{|c|}{$\begin{array}{c}\text { No. of metaphases with different types of chrom. } \\
\text { aberrations }\end{array}$} \\
\hline & & No. & $\%$ Mean $( \pm \mathrm{SE})$ & XY- uni & Auto uni & $\begin{array}{c}\text { Fragment } \\
\text { and/or break }\end{array}$ & $\begin{array}{l}\text { Chain } \\
\text { IV }\end{array}$ \\
\hline Negative control (untreated) & - & 17 & $3.4( \pm 0.48)$ & 11 & 6 & 0 & 0 \\
\hline \multirow{2}{*}{ DMSO } & 1 & 25 & $5.0( \pm 0.70)$ & 15 & 10 & \multirow{2}{*}{0} & \multirow[t]{2}{*}{0} \\
\hline & 2 & 44 & $8.80\left( \pm 0.40^{\mathrm{a}}\right)$ & 30 & 14 & & \\
\hline \multirow{2}{*}{ Extract 23} & 1 & 20 & $4.0( \pm 0.44)$ & 15 & 5 & \multirow{2}{*}{0} & \multirow[b]{2}{*}{0} \\
\hline & 2 & 22 & $4.40\left( \pm 0.55^{\mathrm{b}}\right)$ & 14 & 8 & & \\
\hline \multirow{2}{*}{ Extract 34} & 1 & 24 & $4.80( \pm 0.50)$ & 16 & 8 & \multirow{2}{*}{0} & \multirow{2}{*}{0} \\
\hline & 2 & 27 & $5.40\left( \pm 0.65^{b}\right)$ & 18 & 9 & & \\
\hline \multirow{2}{*}{ Extract 38} & 1 & 15 & $3.0( \pm 0.60)$ & 10 & 5 & \multirow[b]{2}{*}{0} & \multirow[b]{2}{*}{0} \\
\hline & 2 & 21 & $4.20\left( \pm 0.40^{b}\right)$ & 15 & 6 & & \\
\hline $\begin{array}{l}\text { Positive control: cyclophosphamide at } \\
\text { dose } 20 \mathrm{mg} / \mathrm{kg} \text { body weight for } 24 \mathrm{hrs}\end{array}$ & $24 \mathrm{hs}$ & 49 & $9.8\left( \pm 1.71^{\mathrm{a}}\right)$ & 25 & 14 & 8 & 2 \\
\hline
\end{tabular}

Total number of examined metaphases $=500$ metaphase (5 animals/ group); XY-uni: XY- univalent; Auto. Uni.: Autosomal univalent.

a: Significant compared to negative control $(\mathrm{p}<0.01)$; b: Significant compared to DMSO $(\mathrm{p}<0.01)$. 


\section{Chromosomal aberrations in somatic and germ cells}

Tables 10 and 11 show the number and percentage of chromosomal aberrations induced in bone marrow and mouse spermatocytes respectively after treatment for 1 and 2 weeks with different plant extracts dissolved in DMSO. The results show that the percentage of aberrant cells in animals treated with all extracts was statistically non significant compared to the negative control. In the contrary all the plant extracts reduced the number of chromosomal aberrations induced by the solvent DMSO after treatment for 2 weeks $(\mathrm{p}<0.01)$. Also, the plant extract 38 inhibited the number of aberrations induced by the solvent DMSO after treatment for 1 week $(\mathrm{p}<0.05)$ in mouse bone marrow cells (Table 10).

\section{DISCUSSION}

The aim of this study was to identify plant extracts with potential anticancer activity. The multicellular spheroids model was used to select the most active extracts after a cancer monolayers screen. Out of 500 extracts initially screened on HCT116 monolayers, 41 extracts were active. Extracts which were cytotoxic on colon carcinoma spheroids and safe to normal human epithelial cells spheroids and showed pro-apoptotic activity were considered the most active. Three extracts out of the 41 monolayers hits met these criteria: Euphorbia dendroides L. herb, Ononis vaginalis Vahl. herb and Quercus robur L. branches.

According to the authors' knowledge, it is the first time to report anticancer activity for Ononis vaginalis extract, while Euphorbia dendroides and Quercus robur have been shown to possess anticancer activity. Jatrophane diterpenes isolated from Euphorbia dendroides showed antiproliferative activity on nonsmall lung carcinoma (Pesic et al., 2011). Interestingly, these compounds were safe to peripheral blood mononuclear cells (Pesic et al., 2011), in accordance with the non-toxicity of the selected extracts on the normal cells tested in the present study. Euphorbia dendroides has been also identified in extracts screen for in vitro anticancer activity (El Manawaty et al., 2013). The extract of Quercus robur showed in vitro cytotoxic activity against LoVo, PC3, U373 (Frederich et al., 2009) and L1210 (Goun et al., 2002) cancer cell lines. For Ononis vaginalis, no reported anticancer activity was found on searching PubMed website. However, eupatalin flavonoid, a known constituent of Ononis vaginalis (Amer et al., 1989) has been reported for cytotoxic activity against human nasopharynx carcinoma but was isolated from Eupatorium semiserratum (Kupchan et al., 1969).

It is interesting that the selected extracts were not the most potent in the cancer monolayers screen. This is most likely due to the lack of penetration properties of the highly monolayers active extracts. This observation is in compliance with reported results (Fayad et al., 2011) that cancer monolayers and spheroids screens identify different hits from the same drug library. Proapoptotic activity is an interesting end-point and is believed that pro-apoptotic drugs possess preferential toxicity towards cancer cells than normal cells (Frankfurt and Krishan, 2003). This was the reason for including apoptosis as a criteria for hit selection in the study, and pro-apoptotic extracts were selected to be further studied. The advantage of this method that it can be applied invivo by taking samples from treated tumour bearing mice without interference from host cells (Fayad et al., 2009). However, it is important to note that extracts with no pro-apoptotic activity, but cytotoxic on cancer spheroids and safe to normal spheroids are of desired properties and should not be neglected, and are recommended to be further investigated.

The obtained in vitro results were confirmed in our in vivo studies. This was shown in the in vivo results both in the significant anticancer activity of the selected three extracts in the Ehrlich ascites carcinoma model, and in their relative safety in experimental animals.

Treatment with the selected three extracts at dose of one tenth of $\mathrm{LD}_{50}$ increased the life span and non-viable cell count and reduced the tumor volume, tumor weight and viable tumor cell count significantly when compared to that of EAC control group, in particular Quercus robur extract (Table 3, 4). The reliable criteria for judging the value of any anticancer drug is the prolongation of life span of the animals and the decrease of leukemic cells from blood (Gupta et al., 2004). Hence, it may be concluded that the extracts by a direct cytotoxic effect and by arresting the tumor growth, increased the life span of EAC-bearing mice. The three extracts increased the percentage life span significantly, where Quercus robur extract was found to be the most potent among them.

During the toxicological study of the three extracts, the mice behaved normally. Indeed, neither their mobility nor their breathing and feeding have been modified. The LD50 of these extracts were 558, 1479 and $1646 \mathrm{mg} / \mathrm{kg}$ for Euphorbia dendroides, Ononis vaganalis and Quercus robur extracts, respectively, by oral route. Consequently, they could be classified as slightly toxic on the scale of Hodge and Sterner. However, the extract of Euphorbia dendroides was found safe in liver and kidney functions while Ononis vaganalis and Quercus robur extracts were comparatively toxic.

Among short-term mutagenicity/genotoxicity assays, the chromosomal aberration test represents a sensitive protocol widely used for detecting DNA damage (Au and Hsu, 1980; Shelby and Witt, 1995). Chromosomal abnormalities in spermatocytes give information on transmissible genetic damage (Au and Hsu, 1980). Our results showed that the three extracts are safe to genetic material. The percentage of chromosomal aberrations induced in somatic and germ cells after treatment with the extracts for 1 and 2 weeks was statistically not significant in comparing to the control group (saline). In the contrary, all the examined extracts reduced the number of the chromosomal aberrations induced by the solvent DMSO after treatment for 2 weeks $(p<0.01)$. It is worth mentioning that there is no available data about the mutagenic activity of these extracts and this study represents the first data about the mutagenic activity of the three plant extracts.

In conclusion, the authors believe that the applied approach is useful for identification of promising anticancer agents 
and recommend further phytochemical investigations on the identified extracts to isolate the compounds responsible for activity and identify their mechanism of action.

\section{ACKNOWLEDGMENTS}

Financial support and sponsorship: This work was financed by The National Research Centre, Egypt, under the project "Biological and Phytochemical Evaluation of Certain Plant Extracts with anticipated Anticancer Activity" contract agreement no. 9100304 (2010- 2013), Principal Investigator Khaled Mahmoud.

Conflict of Interests: There are no conflicts of interest.

\section{REFERENCES}

Amer, M, Abdel-Kader, M, Mahmoud, Z, Abdel-Salam, N, Yang, S, Mabry, T. Flavonoids of Ononis vaginalis Vahl. Symb. Rev. Latinoamer. Quim, 1989; 20: 152-153.

Au, WW, Hsu, TC. The genotoxic effects of adriamycin in somatic and germinal cells of the mouse. Mutat Res 1980; 79(4): 351-361.

Awad, HM, Fayad, W, El-Hallouty, SM, Farghaly, TA, Abdallah, MM. Anticancer activity of some [1,2,4]triazepino[2,3-a] quinazoline derivatives: monolayer and multicellular spheroids in vitro models. Medicinal Chemistry Research 2016; 25(9): 1952-1957.

Balis, FM. Evolution of anticancer drug discovery and the role of cell-based screening. J Natl Cancer Inst 2002; 94(2): 78-79.

Boulos, L. 1999-2005. Flora of Egypt, vols. 1-4. Al Hadara Publishing, Cairo.

Brown, JM. Tumor hypoxia in cancer therapy. Methods Enzymol, 2007; 435: 297-321.

El Manawaty, M, FAYAD, W, EL-FIKY, NM, WASSEL, GM, EL-MENSHAWI, BS. High-throughput screening of 75 euphorbiaceae and myrtaceae plant extracts for in-vitro antitumor and pro-apoptotic activities on human tumor cell lines, and lethality to brine shrimp. Internat. J. Pharmacy Pharmaceut. Sci 2013; 5: 178-183.

Evans, EP, Breckon, G, Ford, CE. An Air-Drying Method for Meiotic Preparations from Mammalian Testes. Cytogenetics 1964; 3: 289294.

Fayad, W, Fryknas, M, Brnjic, S, Olofsson, MH, Larsson, R, Linder, S. Identification of a novel topoisomerase inhibitor effective in cells overexpressing drug efflux transporters. PLoS One 2009; 4(10): e7238.

Fayad, W, Rickardson, L, Haglund, C, Olofsson, MH, D'Arcy, $\mathrm{P}$, Larsson, $\mathrm{R}$, et al. Identification of agents that induce apoptosis of multicellular tumour spheroids: enrichment for mitotic inhibitors with hydrophobic properties. Chem Biol Drug Des 2011; 78(4): 547-557.

Frankfurt, OS, Krishan, A. Apoptosis-based drug screening and detection of selective toxicity to cancer cells. Anticancer Drugs 2003; 14(7): 555-561.

Frederich, M, Marcowycz, A, Cieckiewicz, E, Megalizzi, V, Angenot, L, Kiss, R. In vitro anticancer potential of tree extracts from the Walloon Region forest. Planta Med 2009; 75(15): 1634-1637.

Friedrich, J, Eder, W, Castaneda, J, Doss, M, Huber, E, Ebner, $\mathrm{R}$, et al. A reliable tool to determine cell viability in complex 3-d culture: the acid phosphatase assay. J Biomol Screen 2007; 12(7): 925-937.

Geran, RI. Protocols for screening chemical agents and natural products against animal tumors and other biological systems. Cancer Chemother Rep 1972; 3: 51-61.

Goun, EA, Petrichenko, VM, Solodnikov, SU, Suhinina, TV, Kline, MA, Cunningham, G, et al. Anticancer and antithrombin activity of Russian plants. J Ethnopharmacol 2002; 81(3): 337-342.

Gupta, M, Mazumder, UK, Kumar, RS, Sivakumar, T, Vamsi, ML. Antitumor activity and antioxidant status of Caesalpinia bonducella against Ehrlich ascites carcinoma in Swiss albino mice. J Pharmacol Sci 2004; 94(2): 177-184.

Husdan, H, Rapoport, A. Estimation of creatinine by the Jaffe reaction. A comparison of three methods. Clin Chem 1968; 14(3): 222238.

Hutchinson, L, Kirk, R. High drug attrition rates--where are we going wrong? Nat Rev Clin Oncol 2011; 8(4): 189-190.

Huxley, AJ, Griffiths, M, Levy, M, Royal Horticultural Society (Great Britain). 1992. The new Royal Horticultural Society dictionary of gardening. Macmillan Press: London.

Inch, WR, McCredie, JA, Sutherland, RM. Growth of nodular carcinomas in rodents compared with multi-cell spheroids in tissue culture. Growth 1970; 34(3): 271-282.

Kobayashi, H, Man, S, Graham, CH, Kapitain, SJ, Teicher, BA, Kerbel, RS. Acquired multicellular-mediated resistance to alkylating agents in cancer. Proc Natl Acad Sci U S A 1993; 90(8): 3294-3298.

Kupchan, S, Sigel, C, Hemingway, R, Knox, J, Udayamurthy, M. Tumor inhibitors-XXXIII: Cytotoxic flavones from eupatorium species. Tetrahedron 1969; 25(8): 1603-1615.

Malloy, HT, Evelyn, KA. The determination of bilirubin with the photoelectric colorimeter. Journal of Biological Chemistry 1937; 119(2): 481-490.

Mellor, HR, Ferguson, DJ, Callaghan, R. A model of quiescent tumour microregions for evaluating multicellular resistance to chemotherapeutic drugs. Br J Cancer 2005; 93(3): 302-309.

Mosmann, T. Rapid colorimetric assay for cellular growth and survival: application to proliferation and cytotoxicity assays. J Immunol Methods 1983; 65(1-2): 55-63.

Pesic, M, Bankovic, J, Aljancic, IS, Todorovic, NM, Jadranin, M, Vajs, VE, et al. New anti-cancer characteristics of jatrophane diterpenes from Euphorbia dendroides. Food Chem Toxicol 2011; 49(12): 3165-3173.

Reitman, S, Frankel, S. A colorimetric method for the determination of serum glutamic oxalacetic and glutamic pyruvic transaminases. Am J Clin Pathol 1957; 28(1): 56-63.

Roberts, DL, Williams, KJ, Cowen, RL, Barathova, M, Eustace, AJ, Brittain-Dissont, S, et al. Contribution of HIF-1 and drug penetrance to oxaliplatin resistance in hypoxic colorectal cancer cells. $\mathrm{Br}$ J Cancer 2009; 101(8): 1290-1297.

Shelby, MD, Witt, KL. Comparison of results from mouse bone marrow chromosome aberration and micronucleus tests. Environ Mol Mutagen 1995; 25(4): 302-313.

Shoemaker, RH. The NCI60 human tumour cell line anticancer drug screen. Nat Rev Cancer 2006; 6(10): 813-823.

Sunila, ES, Kuttan, G. Immunomodulatory and antitumor activity of Piper longum Linn. and piperine. J Ethnopharmacol 2004; 90(2-3): 339-346.

Takagi, A, Watanabe, M, Ishii, Y, Morita, J, Hirokawa, Y, Matsuzaki, T, et al. Three-dimensional cellular spheroid formation provides human prostate tumor cells with tissue-like features. Anticancer Res 2007; 27(1A): 45-53.

Wilbrandt, W. [Behrens methods for calculation of LD50]. Arzneimittelforschung 1952; 2(11): 501-503.

Yosida, TH, Amano, K. Autosomal polymorphism in laboratory bred and wild Norway rats, Rattus norvegicus, found in Misima. Chromosoma 1965; 16(6): 658-667.

\section{How to cite this article:}

Fayad W, El-Hallouty SM, El-Manawaty MA, Mounier MM, Soliman AFM, Yousry AA, Farghaly AA, Fahmy MA, Hasasn ZM, Linder S, Mahmoud K. A systematic multicellular spheroids screening approach lead to the identification of antineoplastic activity in three different plant extracts from the Egyptian flora. $\mathbf{J}$ App Pharm Sci, 2017; 7 (06): 013-022. 